\title{
CONTRIBUTIONS TO OUR KNOWLEDGE OF SOIL
} FERTILITY, xv.

The Action of certain Micro-organisms upon the numbers of Bacteria in the Soll.

By R. Greig-Suith, D.Sc., Macleay Bacteriologist to the Society.

In making counts of soil-bacteria, it is not uncommon to find colonies of Bac. mycoides or of races of Bac. vulgatus spreading over the surface of the nutritive agar. Very often it will be noted that, while the majority of the colonies are covered by the spreading growths, there are a few that are untouched. The mycoides-colony may approach to within two, five, or ten millimetres, and then spread out and surround the colony, leaving a ring of clear agar medium. It is evident that there is some product secreted by these colonies which is obnoxious to the spreading colony, whether it be Bac.mycoides, Bac. vulgatus, or to spreading moulds such as Penicillium or Aspergillus.

An examination of the colonies producing this toxic effect showed that the majority consisted of Actinomyces or Streptothrix, as they have been called. Some of these darkened the medium and were apparently Act. chromogenus. Certain of these colonies were selected, and spotted upon fresh plates, in the centre of which bacteria with spreading colonies were planted. The white forms were found to be very toxic, while the dark forms were feebly toxic to the spreading Bac. vulgatus.

The apparent toxicity of these Actinomyces-forms is interesting when one is considering the nature of the limiting factor in soils. This is considered to be protozoal by Russell and others, but as the infection of sterilised soils with protozoa alone, does not introduce the limiting factor, as has been shown by Russell, by Goodey, and by the writer, there are doubts regarding the validity of Russell's contention. Whatever the cause of the 
limitation may be, it is apparently something which is slowgrowing, for an infection with $5 \%$ of raw soil only begins to show a limiting action upon the fortieth day. It is also something, like the larger protozoa, which can be retained by cottonwool filters. These characters would apply to the Actinomycetes which have the property of growing slowly in felted masses capable of being retained by cotton. wool with the particles of soil and the larger protozoa. It appeared possible, therefore, that, in the Actinomycetes, and possibly in an excessive growth of them, we might find the limiting factor for which bacteriologists have been seeking.

Russell and Hutchinson's researches would appear to negative this possibility, for they found that the Actinomycetes were less affected than other forms by toluening; in fact, that immediately after toluening they were the predominating species of microorganisms, and they retained this position for nine days. Of the two forms of Actinomyces, the white and the brown, the latter predominates in raw soil, while the former is conspicuous in toluened soil. Owing to the presence of the white form in toluened soil, in which the limiting factor had been destroyed, Russell and Hutchinson naturally did not test the Actinomycetes to see if they could functionate as the limiting factor. Their apparent toxicity upon agar plates, however, was so conspicuous, that I considered a test was necessary to make their position definite.

Among the species which appeared to be most toxic, three were picked out as being the most promising. Two of these, Nos. 10 and 14, were much the same, and grew as dirty white crusts on nutrient agar; 14 was a trifle darker than 10 . Both adhered firmly to the agar surface. The third, No.11, formed a loose, yellow growth, part of which came away easily from the agar; microscopically, it appeared as a rod with a tendency to grow in threads At first, it produced a yellow pigment, especially upon Lipman-Brown agar, which diffused through the medium. Cultural experiments showed that ordinary nutrient agar was the best for obtaining growths of these species; fluid media were quite unsuitable for growing them in any quantity. 
While using the Lipman-Brown medium for enumerating soilbacteria, certain colonies were found growing on the undersurface of the agar, and preventing the growth of bacterial colonies upon the upper surface. These toxic bacteria, termed provisionally T.P.2, grew scantily upon the surface of the Lipman-Brown agar, but well upon ordinary nutrient agar. This bacillus and the three Actinomycetes were tested upon sterilised soil to determine their possible toxic action upon the soil-flora.

A quantity of garden-soil was heated for an hour at $100^{\circ}$, and divided into portions which, after having had the moisturecontent raised to $10 \%$ with suspensions of the micro-organisms, were put into wide-mouthed, sterile bottles which were plugged with cotton-wool, weighed, and set aside in the laboratory. The temperature varied from $22^{\circ}$ to $26^{\circ}$ except towards the end of the experiment, when it fell gradually to $16^{\circ}$. The moisturecontent was maintained by the occasional addition of sterile water, and portions were abstracted from time to time, and the bacteria counted in the usual manner. The medium employed for the enumeration was Lipman-Brown agar with the addition of $0.05 \%$ of Lemco meat-extract, which gave a more uniform count in the triplicate plates.

BACTERIA IN MILLIONS PER GRAM OF DRY SOIL.

\begin{tabular}{|c|c|c|c|c|c|c|c|c|c|c|c|}
\hline Days. & 1 & 11 & 18 & 31 & 40 & 49 & 56 & 63 & 88 & 125 & 357 \\
\hline Control soil & $0 \cdot 1$ & 95 & 95 & 78 & 65 & 102 & 89 & 63 & 36 & 46 & 8 \\
\hline Actino. 10 & 0.5 & 98 & 81 & 54 & 40 & 54 & 33 & 49 & 26 & 38 & 6 \\
\hline Actino. $11 \ldots$ & & & 62 & 51 & 33 & 41 & 39 & 46 & 30 & 21 & 2 \\
\hline Actino. $14 \ldots$ & $0 \cdot 4$ & 104 & 104 & 80 & 58 & 65 & 75 & 64 & 41 & 36 & $12^{*}$ \\
\hline Bac. T.P. $2 \ldots$ & $\ldots$ & 102 & 260 & 54 & 63 & 58 & 43 & 44 & 23 & 40 & 4 \\
\hline
\end{tabular}

* By an accident, the water-content was raised to $14 \%$.

In counting the colonies, it is not always easy to distinguish a bacterial colony from a mould; especially is this the case with the Actinomyces-colonies when they are deep in the agar, but, so far as was possible, the moulds were excluded in the counts. The colonies of Actino. No.10 were easy to recognise on account of their yellowish colour. 
The numbers show that the addition of the moulds and of the toxic bacteria had a small though consistent effect in reducing the numbers of bacteria after an interval of some thirty days; for when the counts are plotted, the control-curve is generally higher than the others. The reduction of the numbers, however, was not pronounced, and we must therefore conclude that the moulds and bacteria used in the experiment do not constitute what is recognised as the limiting factor. This had not been completely eliminated from the soils, for its effect was made evident between the 125 th and the 357 th day.

Shortly after the start of the last experiment, another was prepared to determine the effect of three of the micro-organisms upon raw, toluened and heated soils. The moisture of a gardensoil was raised to $6 \%$ with sterile distilled water, and the soil was divided into three portions. One was treated for two days with $2 \%$ of toluene, and aired off. A second was heated for two and a half hours at $97^{\circ}$, and, with the third portion, was aired so as to give all three portions the same air-treatment. The portions were subdivided, treated with the respective organisms, and had the moisture-contents raised to $10 \%$.

BACTERIA IN MILLIONS PER GRAM OF DRY SOIL.

\begin{tabular}{|c|c|c|c|c|c|c|c|c|c|}
\hline \multicolumn{2}{|c|}{ Days. } & $1-2$ & 15 & 21 & 28 & 43 & 78 & 94 & 317 \\
\hline Raw soil. & $\begin{array}{l}\text { Control } \\
\text { Actino. } 10 \\
\text { Actino. } 14 \\
\text { Bac. T.P.2 }\end{array}$ & $\begin{array}{r}10 \\
10 \\
9 \\
12\end{array}$ & $\begin{array}{l}\cdots \\
\cdots \\
\cdots \\
\cdots\end{array}$ & $\begin{array}{l}22 \\
20 \\
32 \\
17\end{array}$ & $\begin{array}{l}26 \\
21 \\
17 \\
18\end{array}$ & $\begin{array}{l}\cdots \\
\cdots \\
\cdots \\
\cdots\end{array}$ & $\begin{array}{l}6 \\
5 \\
7 \\
7\end{array}$ & $\begin{array}{l}6 \\
4 \\
5 \\
5\end{array}$ & $\begin{array}{l}3 \\
4 \\
3 \\
3\end{array}$ \\
\hline Toluened soil. & $\begin{array}{l}\text { Control } \\
\text { Actino. } 10 \\
\text { Actino. } 14 \\
\text { Bac. T.P.2 }\end{array}$ & $\begin{array}{l}10 \\
10 \\
11 \\
12\end{array}$ & $\begin{array}{c}\ldots \\
\ldots \\
\ldots \\
160\end{array}$ & $\begin{array}{r}56 \\
61 \\
115 \\
110\end{array}$ & $\begin{array}{l}47 \\
58 \\
78 \\
59\end{array}$ & $\begin{array}{l}\cdots \\
\cdots \\
\cdots \\
\cdots\end{array}$ & $\begin{array}{l}66 \\
86 \\
71 \\
66\end{array}$ & $\begin{array}{l}59 \\
71 \\
41 \\
49\end{array}$ & $\begin{array}{l}49 \\
47 \\
53 \\
41\end{array}$ \\
\hline Heated soil. & $\begin{array}{l}\text { Control } \\
\text { Actino. } 10 \\
\text { Actino. } 14 \\
\text { Rac. T.P.2 }\end{array}$ & $\begin{array}{l}1 \\
1 \\
1 \\
4\end{array}$ & $\begin{array}{r}81 \\
52 \\
98 \\
356\end{array}$ & $\begin{array}{l}\cdots \\
\cdots \\
\cdots \\
\cdots\end{array}$ & $\begin{array}{r}84 \\
57 \\
108 \\
107\end{array}$ & $\begin{array}{l}\cdots \\
\cdots \\
\cdots \\
\cdots\end{array}$ & $\begin{array}{l}45 \\
66 \\
44 \\
71\end{array}$ & $\begin{array}{l}44 \\
56 \\
35 \\
35\end{array}$ & $\begin{array}{l}31 \\
26 \\
27 \\
24\end{array}$ \\
\hline Raw soil. & $\begin{array}{l}\text { Acetone, } 2 \% \\
\text { Acetone, } 5 \%\end{array}$ & $\begin{array}{l}29 \\
12\end{array}$ & $\begin{array}{l}40 \\
67\end{array}$ & $\begin{array}{l}\cdots \\
\cdots\end{array}$ & $\begin{array}{l}36 \\
50\end{array}$ & $\begin{array}{l}46 \\
94\end{array}$ & $\begin{array}{l}\cdots \\
\cdots\end{array}$ & $\begin{array}{l}\cdots \\
\cdots\end{array}$ & $\begin{array}{l}19 \\
45\end{array}$ \\
\hline
\end{tabular}

The experiment confirms the previous one in showing that the 
organisms have little or no action in bringing about a pronounced limiting effect upon the numbers of bacteria in the soil. The untreated soil had recovered from its air-drying by the 78 th day, and had become normal; while the toluened and heated soils had not arrived at this condition by the close of the experiment on the 317 th day. From a general glance at the numbers, we see that, in the heated soil, the numbers rapidly rise to a maximum and then fall; while, in the toluened soil, the numbers slowly rise, and the height of the curve is maintained for a longer time. I have already suggested that the effect of toluening appears to be to liberate nutrients, while heat seems to destroy toxins; but this is only a suggestion, for there is undoubtedly some other factor which is more potent. Possibly this is the alteration of the flora, which masks anything but a general difference between the results of the two methods of treatment.

The small experiment with acetone was introduced to test the contention of Buddin, ${ }^{*}$ who said that it did not act as a volatile disinfectant, that is, it did not produce any partial sterilisationeffect, until $5 \cdot 8 \%$ by weight had been added to the soil. From his experiment with acetone, which is a fat-solvent, he concluded that the volatile disinfectants do not influence the soil by reason of their power of dissolving the fatty matter (agricere) and facilitating the solution of the soil-constituents, as was suggested by me. Small as my experiment is, it shows that Buddin's assertion is too sweeping, for the action of acetone is one of degree, its action being much the same, though more feeble than toluene The addition of $5 \%$ (by volume $=4 \%$ by weight) to the soil brought about an effect similar to that of $2 \%$ of toluene, and $2 \%$ of acetone had a less pronounced action. The high count on the second day, with the smailer amount, is peculiar and points to a stimulating effect. With regard to the fat-dissolving action of the volatile disinfectants, I have already said that the action is only one of many, and that it plays a part, though probably a small one, in the greater question of soil-fertility. 


\section{$2 \mathrm{BHL}$ Biodiversity Heritage Library}

Greig-Smith, Robert. 1917. "Contributions to our knowledge of soil fertility, xv. The action of certain micro-organisms upon the numbers of bacteria in the soil." Proceedings of the Linnean Society of New South Wales 42, 162-166. https://doi.org/10.5962/bhl.part.4850.

View This Item Online: https://www.biodiversitylibrary.org/item/30101

DOI: https://doi.org/10.5962/bhl.part.4850

Permalink: $\underline{\text { https://www.biodiversitylibrary.org/partpdf/4850 }}$

\section{Holding Institution}

MBLWHOI Library

\section{Sponsored by}

MBLWHOI Library

\section{Copyright \& Reuse}

Copyright Status: NOT_IN_COPYRIGHT

This document was created from content at the Biodiversity Heritage Library, the world's largest open access digital library for biodiversity literature and archives. Visit BHL at https://www.biodiversitylibrary.org. 